\title{
Characterization of the Reaction of North Dakota Dry Bean Cultivars to Three Races of Colletotrichum lindemuthianum
}

\author{
L. E. del Río, R. S. Lamppa, and P. L. Gross, Department of Plant Pathology, North Dakota State University, \\ Fargo 58105
}

\begin{abstract}
del Río, L. E., Lamppa, R. S., and Gross, P. L. 2003. Characterization of the reaction of North Dakota dry bean cultivars to three races of Colletotrichum lindemuthianum. Plant Dis. 87:263265.

Colletotrichum lindemuthianum, causal agent of anthracnose, a serious disease of dry bean, had been prevalent mostly in the eastern United States and Michigan. In 2001, the disease was observed affecting several commercial bean fields in North Dakota. To assess the potential impact of this pathogen on the North Dakota dry bean industry, 30 of the most widely planted cultivars were inoculated with races 7, 73, and 89 of $C$. lindemuthianum. Race 73 is present in Michigan, and has been detected in recently North Dakota and Manitoba, while races 7 and 89 are currently present in Michigan and Ontario. All cultivars were spray inoculated with a suspension of $10^{6}$ conidia/ $\mathrm{ml}$ in the greenhouse and evaluated for disease reaction using a 0 -to- 9 scale 8 days after inoculation. Most kidney beans were susceptible to race 7, but resistant to races 73 and 89. 'Isles' and 'Drake' were the only kidney beans resistant to all three races. All pinto beans were susceptible to races 73 and 89 except 'Topaz', which was moderately resistant to race 73 but susceptible to race 89 . Most pinto beans were resistant or moderately resistant to race 7. Navy bean cvs. Newport and Envoy were resistant to all three races; however, 'Norstar', the most widely planted navy bean cultivar, was susceptible to all three races. Research is being conducted to identify germplasm with resistance to these races. To reduce the possibility of spreading this pathogen to new fields in the region, the use of noncertified seed should be discouraged among producers, and fields used for seed production should be monitored very carefully.
\end{abstract}

Bean anthracnose, caused by the fungus Colletotrichum lindemuthianum (Sacc. \& Magnus) Lams.-Scrib., is a devastating disease that is prevalent in temperate regions of the world. The economic importance of $C$. lindemuthianum in North America had steadily declined since the early 1920s, due to the generalized use of resistant germplasm and of certified pathogen-free seeds (8). The increased movement of plant materials among neighboring regions in recent years has resulted in frequent, accidental introductions of new races of the pathogen, with subsequent disease outbreaks. In 1982, the epsilon race, also known as race 65 (2), was detected in Ontario, presumably introduced on cranberry bean seeds (16). In 1996, race 65 was detected in Michigan (1). In 1993, the alpha-Brazil race, also known as race 89 (2), was detected in field trial locations south of Ontario; the source

Corresponding author: L. del Río

E-mail: Luis.delRio-Mendoza@ndsu.nodak.edu

This work was supported in part by grant \# 83415120-1648 from the Northarvest Bean Growers Association.

Accepted for publication 7 October 2002.

Publication no. D-2002-1223-01R

(C) 2003 The American Phytopathological Society of the disease was traced back to Michigan (15). Race 73 has been isolated from Michigan bean fields (1), but its presence has not been confirmed in Ontario. Anthracnose was observed for the first time in Manitoba bean fields during the 1999 season (17) and in North Dakota during the 2001 season (3). Race 73 was identified in samples from both sites $(3,4)$. Based on these events, races other than 73 also may occur in North Dakota in the near future. This study was conducted to assess the potential impact of the introduction of races 7, 73, and 89 of $C$. lindemuthianum on the bean industry in North Dakota.

\section{MATERIALS AND METHODS}

Thirty dry bean cultivars planted in North Dakota and Minnesota were selected for this study. Cultivars representing the red kidney, pinto, navy, and cranberry bean market classes were evaluated for their reaction to races 7, 73, and 89 of $C$. lindemuthianum (Table 1). One isolate of each race was inoculated on three groups of 10 seedlings per cultivar. Scores of individual plants were averaged within each replication. The experiment was repeated once. Data from both experiments were pooled after analysis determined that variances among experiments were homogeneous.

Seed were sown in 6-by-6-cm plastic square pots containing Sunshine Soil Mix \# 1 (Sun-Gro Horticulture, Bellevue, WA) in late March and early April 2001. Pots were placed in a greenhouse maintained at $22 \pm 2^{\circ} \mathrm{C}$ and $14 \mathrm{~h}$ of daylight for 12 days prior to inoculation.

Isolates of races 7, 73, and 89 were obtained from J. D. Kelly (Michigan State University, East Lansing, MI). Bean juice agar (11) was used to produce inoculum of race 7, and Mathur's medium (9) for races 73 and 89 . Colonies were grown for 7 to 14 days at $20^{\circ} \mathrm{C}$ in the dark. Conidia were collected by rubbing the surface of the colonies with a cotton swab and then suspending the conidia in a solution of distilled water and $0.01 \%$ Tween 80 (vol/vol). The suspension then was filtered through cheesecloth, adjusted to $1 \times 10^{6}$ conidia/ml, and sprayed on the abaxial side of fully expanded primary bean leaves until runoff. The inoculum was delivered using a Paasche airbrush with $137 \mathrm{kPa}$ of pressure. Inoculated plants were incubated in a moist chamber at $>90 \%$ relative humidity and $20 \pm 2^{\circ} \mathrm{C}$ with $14 \mathrm{~h}$ of fluorescent light daily for 5 days. Plants then were returned to the greenhouse and, after 3 days, disease reaction was measured by visually estimating the percentage of dead leaf tissue on each seedling. These values were averaged within each replication and then across replications for each cultivar. Means were transformed using a 0 -to- 9 scale, where a 0 indicated less than $9 \%$ of the plant tissue affected, and each unit increase represented a $10 \%$ increment in the percentage of dead plant tissue. Cultivars were considered susceptible if they scored $\geq 4$, moderately resistant if $<4$ or $\geq 2$, and resistant if $<2$.

\section{RESULTS AND DISCUSSION}

Most of the cultivars evaluated were susceptible to one or more races of $C$. lindemuthianum (Table 1). All kidney beans were resistant or moderately resistant to races 73 and 89 of C. lindemuthianum but susceptible to race 7 except for 'Isles' and 'Drake', which were resistant to all three races. Both cranberry bean cultivars were susceptible to all three races except 'Taylor Horticultural', which was resistant to race 73 . All pinto beans were susceptible to races 73 and 89 except 'Topaz', which was resistant to race 73 . Reaction of pinto beans to race 7 was variable. Navy beans 'Envoy', 'Newport', 'Fleetwood', and 'Upland' were resistant or moderately resistant to all three races while 'Aspen', 'Albion', 'Navigator', and 
'Mayflower' were resistant to race 7 but susceptible to races 73 and 89 . 'Norstar' was the only navy bean susceptible to all three races. Resistance against race 73 often was associated with resistance to race 89, except for 'Vista', 'Schooner', 'Topaz', and 'Taylor Horticultural'. 'Vista' was the only cultivar that was resistant to race 89 but susceptible to race 73 .

An assessment of the reaction of bean cultivars to races of $C$. lindemuthianum was needed to determine the potential economic impact of the pathogen on the dry bean industry in North Dakota and to assist in breeding resistant germplasm. All of the pinto cultivars except 'Topaz' and five of the navy bean cultivars evaluated were susceptible to races 73 and 89 . Topaz was susceptible to race 89 but resistant to race 73. A survey of 183 bean producers in Minnesota and North Dakota indicated that over $50 \%$ of the bean hectarage in the 2000 season was planted to pinto bean, while $23 \%$ was planted to navy bean (6). The same survey indicated that 'Topaz', the only pinto bean that was moderately resistant to race 73 , was planted on less than 400 ha in the 2000 season, while 'Maver-

Table 1. Reaction of kidney, cranberry, pinto, and navy bean cultivars to races 7, 73, and 89 of Colletotrichum lindemuthianum 8 days after inoculation ${ }^{\mathrm{a}}$

\begin{tabular}{|c|c|c|c|}
\hline \multirow[b]{2}{*}{ Cultivars } & \multicolumn{3}{|c|}{ Disease reaction $^{\mathbf{b}}$} \\
\hline & Race 7 & Race 73 & Race 89 \\
\hline \multicolumn{4}{|l|}{ Kidney beans } \\
\hline Drake & $\mathrm{R}(1)$ & $\mathrm{R}(0)$ & $\mathrm{R}(0)$ \\
\hline Isles & $\mathrm{R}(0)$ & $\mathrm{R}(0)$ & $\mathrm{R}(0)$ \\
\hline California Dark & S (9) & $\mathrm{R}(0)$ & $\mathrm{R}(0)$ \\
\hline California Early & S (9) & $\mathrm{R}(0)$ & $\mathrm{R}(0)$ \\
\hline Montcalm & S (8) & $\mathrm{R}(0)$ & $\mathrm{R}(0)$ \\
\hline Sacramento & S (9) & $\mathrm{R}(0)$ & $\mathrm{R}(0)$ \\
\hline Foxfire & S (8) & MR (2) & MR (3) \\
\hline \multicolumn{4}{|l|}{ Cranberry beans } \\
\hline Taylor Horticultural & $\mathrm{S}(9)$ & $\mathrm{R}(1)$ & S (5) \\
\hline Cran-09 & S (8) & S (4) & $\mathrm{S}(9)$ \\
\hline \multicolumn{4}{|l|}{ Pinto beans } \\
\hline Chase & $\mathrm{R}(1)$ & S (7) & S (7) \\
\hline Maverick & $\mathrm{R}(1)$ & S (6) & S (7) \\
\hline Topaz & MR (3) & $\mathrm{R}(1)$ & S (9) \\
\hline Fargo & MR (2) & $\mathrm{S}(9)$ & $\mathrm{S}(9)$ \\
\hline Focus & MR (2) & S (9) & S (9) \\
\hline Othello & MR (2) & $\mathrm{S}(9)$ & $\mathrm{S}(9)$ \\
\hline Fiesta & S (4) & S (9) & S (9) \\
\hline Hatton & S (4) & S (9) & $\mathrm{S}(9)$ \\
\hline Winchester & S (4) & S (9) & S (9) \\
\hline Olathe & S (6) & $\mathrm{S}(9)$ & $\mathrm{S}(9)$ \\
\hline \multicolumn{4}{|l|}{ Navy beans } \\
\hline Envoy & $\mathrm{R}(0)$ & $\mathrm{R}(0)$ & $\mathrm{R}(0)$ \\
\hline Newport & $\mathrm{R}(0)$ & $\mathrm{R}(0)$ & $\mathrm{R}(0)$ \\
\hline Fleetwood & $\mathrm{R}(1)$ & $\mathrm{R}(0)$ & $\mathrm{R}(0)$ \\
\hline Upland & MR (2) & $\mathrm{R}(1)$ & $\mathrm{R}(0)$ \\
\hline Schooner & $\mathrm{R}(0)$ & $\mathrm{R}(1)$ & S (8) \\
\hline Vista & $\mathrm{R}(0)$ & $\mathrm{S}(9)$ & $\mathrm{R}(0)$ \\
\hline Aspen & $\mathrm{R}(0)$ & S (8) & S (9) \\
\hline Albion & $\mathrm{R}(0)$ & $S(7)$ & $\mathrm{S}(9)$ \\
\hline Navigator & $\mathrm{R}(0)$ & S (9) & S (7) \\
\hline Mayflower & $\mathrm{R}(0)$ & S (9) & S (8) \\
\hline Norstar & S (4) & S (9) & S (9) \\
\hline
\end{tabular}

a Seedlings inoculated on their primary leaves until runoff with $1 \times 10^{6}$ conidia $/ \mathrm{ml}$.

${ }^{\mathrm{b}}$ Disease reaction based on a 0 -to- 9 scale (numbers in parenthesis) where $0=0$ to $9 \%$ dead plant tissue and each unit increase represent a $10 \%$ increase in dead plant tissue. Susceptible cultivars (S) scored $\geq 4$ in the scale, moderately resistant cultivars (MR) scored $<4$ and $\geq 2$, and resistant cultivars (R) scored $<2$. Scores are average of two experiments with four replications each. seedborne pathogens already present in the region (12). In 1999, less than $6 \%$ of bean producers in Minnesota and North Dakota used bin-run seed to plant their fields (7), but more than $12 \%$ did in the 2000 season (6). This situation could readily result in an increase in anthracnose.

Pyramiding race-specific resistant genes Co-1 and Co-2, of Andean and Mesoamerican origin, respectively (13), has been proposed to control anthracnose in North America (19). The combined activity of both genes confers resistance against all races currently present in the United States (10). However, pyramiding genes could be an expensive and lengthy procedure, especially if none of the resistance genes are already present in the breeding lines. Thus, protecting 'Norstar' will demand more efforts than those required to protect 'Mayflower' or 'Maverick', because the latter two already carry the $\mathrm{Co}-1$ gene. An alternative to pyramiding both genes, $\mathrm{Co}-1$ and $\mathrm{Co}$-2, in germplasm that does not have either of them, would be to use single genes that provide as broad protection as the one offered by $\mathrm{Co}-\mathrm{I}$ and $\mathrm{Co}-2$ combined. Examples of such genes are the Mesoamerican gene $\mathrm{Co}-4^{2}$, which has already been incorporated into some breeding lines $(5,18)$, and for which molecular markers also have been identified (20), and the $C o-l^{2}$ gene present in the Andean differential 'Kaboon' (10). Protection provided by each of these genes encompasses races of both gene pools.

Anthracnose has been detected in a few North Dakota fields (3), but not in Minnesota. To reduce the possibilities of spreading the pathogen into new areas in both states, the use of bin-run seed should be avoided or discontinued, and a zero tolerance policy for anthracnose on commercial seed lots and tighter control of seed production fields should be established in the region.

\section{LITERATURE CITED}

1. Balardin, R. S., and Kelly, J. D. 1996. Identification of race 65-Epsilon of bean anthracnose (Colletotrichum lindemuthianum) in Michigan. Plant Dis. 80:712.

2. Balardin, R. S., and Kelly, J. D. 1997. Recharacterization of Colletotrichum lindemuthianum races. Bean Improv. Coop. 40:126127.

3. del Río, L. E., Lamppa, R. S., and Gross, P. L. 2002. First report of dry bean anthracnose (Colletotrichum lindemuthianum) race 73 in North Dakota. Plant Dis. 86:562.

4. del Río, L. E., Lamppa, R. S., Gross, P. L., Brolley, B., and Prischmann, J. Identification of Colletotrichum lindemuthianum race 73 in Manitoba, Canada. Can. J. Plant Pathol. In press.

5. Kelly, J. D., Afanador, L., and Cameron. L. S. 1994. New races of Colletotrichum lindemuthianum in Michigan and implications in dry bean resistance breeding. Plant Dis. 78:892894.

6. Lamey, H. A., Zollinger, R. K., Luecke, J. L., Berglund, D. R., Glogoza, P. A., and Grafton, K. F. 2001. 2000. Dry bean grower survey of pest problems and pesticide use in Minnesota and North Dakota. N. D. State Univ. Ext. Rep. 
No. 72.

7. Lamey, H. A., Zollinger, R. K., McMullen, M. P., Luecke, J. L., Venette, J. R., Berglund, D. R., Grafton, K. F., and Glogoza, P. A. 2000. 1999 dry bean grower survey of pest problems and pesticide use in Minnesota and North Dakota. N. D. State Univ. Ext. Rep. No. 64.

8. Lenné, J. M. 1992. Colletotrichum diseases of legumes. Pages 134-166 in: Colletotrichum: Biology, Pathology and Control. J. A. Bailey and M. J. Jeger, eds. CAB International, Wallingford, UK.

9. Mathur, R. S., Barnett, H. C., and Lilly, V. G. 1950. Sporulation of Colletotrichum lindemuthianum in culture. Phytopathology 40:104114.

10. Melotto, M., and Kelly, J. D. 2000. An allelic series at the $\mathrm{Co}-1$ locus conditioning resistance to anthracnose in common bean of Andean origin. Euphytica 116:143-149.

11. Romanowski, R. D., Kuc, J., and Quakken- bush, F. W. 1962. Biochemical changes in seedlings of bean infected with Colletotrichum lindemuthianum. Phytopathology 52:1259-1263.

12. Schwartz, H. F., and Morales, F. J. 1989. Seed pathology. Pages 413-431 in: Bean Production Problems in the Tropics. H. F. Schwartz and M. A. Pastor-Corrales, eds. CIAT, Cali, Colombia.

13. Sicard, D., Michalakis, Y., Dron, M., and Neema, C. 1997. Genetic diversity and pathogenic variation of Colletotrichum lindemuthianum in the three centers of diversity of its host, Phaseolus vulgaris. Phytopathology 87:807-813.

14. Tu, J. C. 1981. Anthracnose (Colletotrichum lindemuthianum) on white bean (Phaseolus vulgaris L.) in Southern Ontario: Spread of the disease from an infection focus. Plant Dis. 65:477-480.

15. Tu, J. C. 1994. Occurrence and characterization of the alpha-Brazil race of bean anthrac- nose (Colletotrichum lindemuthianum) in Ontario. Can. J. Plant Pathol. 16:129-131.

16. Tu, J. C., Sheppard, J. W., and Laidlaw, D. M. 1984. Occurrence and characterization of the epsilon race of bean anthracnose in Ontario. Plant Dis. 68:69-70.

17. Xue, A. G, Tuey, H. J., and Platford, R. G. 2000. Diseases of field bean in Manitoba in 1999. Can. Plant Dis. Surv. 80:75-76.

18. Young, R. A., and Kelly, J. D. 1996. Characterization of the genetic resistance to Colletotrichum lindemuthianum in common bean differential cultivars. Plant Dis. 80:650-654.

19. Young, R. A., and Kelly, J. D. 1997. RAPD markers linked to three major anthracnose resistance genes in common bean. Crop Sci. 37:940-946

20. Young, R. A., Melotto, M., Nodari, R. O., and Kelly, J. D. 1998. Marker-assisted dissection of the oligogenic anthracnose resistance in the common bean cultivar, 'G2333'. Theor. Appl. Genet. 96:87-94. 